\title{
COMPARATIVE ANALYSIS OF STRUCTURE-FROM-MOTION SOFTWARE'S -AN EXAMPLE OF LETYCHIV (UKRAINE) CASTLE AND CONVENT BUILDINGS
}

\author{
P. Lewińska ${ }^{\text {a*}}$, K. Pargieła ${ }^{\text {a }}$ \\ a AGH University of Science and Technology, Faculty of Mining Surveying and Environmental Engineering, A. Mickiewicza Av. \\ 30, 30-059 Cracow, Poland
}

Received: 14.10.2018 / Accepted: 12.11.2018/ Revised: 20.11.2018 / Available online: 15.12.2018

DOI: 10.2478/jaes-2018-0021

KEY WORDS: Structure-from-motion, heritage, point clout, Latyczów, Ukraine, photogrammetry.

\begin{abstract}
:
Letychiv (pl. Latyczów) is a town located in central Ukraine in the Khmelnytskyi Oblast. It has a unique and complicated history. Second World War left it in ruin, destroying buildings, infrastructure and decimating its once large population. Perhaps the most prominent part of the town currently is the building Dominican convent with adjoin Letychiv Assumption Church. This object is surrounded by what is left of the previously impressive Letychiv Castle, founded by Jan Potocki in 1598. Past 30 years have been dedicated by this small Catholic parish towards rebuilding monastery-castle-church complex. Since this is an ongoing project, it was decided to perform a photographic inventory of the current state of the construction and to create a 3D digital model of the castle, facade of the church and monastery, and the altar. This task have proven to be difficult due to complicated structure of the object. Facades and inner parts of the church are almost white with limited number of distinctive elements, painted in pail gold. Elements other than white are almost identical to each other. It leads to various errors in the processing of Structure-from-motion. This article describes how various versions of SfM algorithm work thru mention difficulties, compares results in terms of accuracy, level of detail and overall look. It also describes how SfM can help to document various stages of restoration of important historical objects.
\end{abstract}

\section{INTRODUCTION}

Recent years brought a growing need for documenting cultural heritage monuments to preserve their current state. 3D digital models are used during reconstruction or renovation, but sometimes may become the only documentation of the building if it dilapidates. Often terrestrial laser scanning provides data for non-parametric modelling. This method is accurate and can be used in almost all instances, but it is also expensive. Photogrammetry has come to aid with Structure-from-motion algorithms that produce a point cloud and fully textured 3D mesh model of the object based only on photographs (Verhoeven, G., 2012). This method, being not as accurate as terrestrial laser scanning, is rapidly becoming a cheaper and faster alternative (De Reu, J., 2013). Since the method itself has many implementations it has become important to compare popular software's regarding quality of created 3D models and point clouds (Green, S., 2014). An example of Latyczew Church/Monastery/Castle complex was used. It was chosen due to a variety of objects to be modelled from the brick wall (a large number of distinctive elements), white facades (lack of details), to golden altar (reflective elements). Latyczew Church/Monastery/Castle was in need of a 3D model of its current state due to extensive ongoing renovation.

\section{STUDY AREA - ASSUMPTION CHURCH, DOMINICAN MONASTERY, CASTLE IN LATYCZÓW}

Letychiv (pl. Latyczów) is a town located in central Ukraine in the Khmelnytskyi Oblast. It has a unique and complicated history. It was most probably founded in the XIV century by the noble Koaratowicz family after Tataras were removed from the Podole area. In 1366 the town and all of the Podole region was moved under the regime of Polish king Casimir III the Great (Kazimierz III Wielki). The town was destroyed many times due to its placement on the track of important north-south and eastwest routes. In 1637 polish King Sigismund I the Old (Zygmunt I Stary) honored the town with Magdeburg Law. It wasn't, however, until 1598 when Jan Potocki took hold of large parts of the land and decided to surround Latyczów with a stone castle. This lead to creation of a castle-town complex surrounded by three smaller villages. Construction of the castle did not stop the invasions, but allowed the town to be more protected from burning it to the ground as it was done some many times before. A castle was constructed with local rock (in most parts limestone) with four fortified towers. Since the town was naturally surrounded by Volk River a moat was done to secure the town and a drawbridge was built into castle walls.

The first parish in Latyczów was probably established in 1430 but the wooden church was destroyed along with the town in 1453. It wasn't until the end of XVI century that two

\footnotetext{
* Corresponding author.
} 
missionaries of Dominican Order came providing the town with a constant spiritual guide. Not long after the convent was funded it was given charge over a stone church build probably during the construction of the castle. The church itself was placed just outside the castle, it had small fortified towers hidden within its shape. Over the years to the basic, round shape of the church two aisles ware added and a porch. Around 1606 the Monastery was attached to the church, it was built in Renaissance, Mannerism style to match the temple. The church became famous due to the image of Mother Mary of Latyczów. A copy of famous Santa Maria Maggiore church painting (Salus Populi Romani) done in the second half of the XVI century by an unknown artist. Painting was entrusted to the Dominican Order by the Pope, and then transported it to the Latyczów Church. The painting has become famous for many alleged miracles that occurred in its presents and quickly become one of the most recognizable images of Mother Mary with Child in the middle Europe.

After the First World War the area was placed under the jurisdiction of Soviets. The church and the monastery were closed. Priests, monks and many parishioners were removed, some murdered. The buildings were used as warehouses and stables. In the region electricity, schools, roads and other infrastructure were built. But this has not mitigated with human losses during the time of great Holodomor. Second World War left Latyczów in ruin, destroying buildings, infrastructure and decimating its once large population. Records suggest that within the Latyczew church complex and near surroundings two separate prisons were held at different times. During Nazi occupation a Jewish ghetto whose prisoner was executed in 1942, later a prison for those oppose to Soviet Union politics was established. Not much is known about the prisoners.

Currently, the town is slowly coming back to its previous glory. Perhaps most prominent is the building of the Monastery with the adjoin Letychiv Assumption Church. This object is surrounded by what is left of previously impressive Letychiv Castle (Szumił, H.I., 2015). During the past 30 years, a small catholic parish rebuild this convent-castle-church complex. Since this is an ongoing project, it was decided to perform a photographic inventory of the current state of the construction and to create a 3D digital model of the castle tower, outside facade of the church and monastery, and middle altar with the use of Structure-from-motion method.

\section{STRUCTURE-FROM-MOTION ALGORITHMS}

Structure-from-motion algorithms are a relatively new part of photogrammetry (Doneus, M., 2011). They allow for almost automatic creation of 3D Mesh models, textured Mesh models and point clouds from a series of pictures (Chiabrando, F., 2015; Shah, Y., 2018). Algorithms allow to recognize highcontrast features (of the object), follow their movement through a series of pictures and produce a sparse point cloud based on feature placement in the image series (Rayn I.C., 2015). In order to perform that a series of filters is applied to the pictures in order to worsen quality and find most prominent features of the element. In most current instalments cameras do not need to be pre-calibrated, camera calibration is done within the algorithm. Software possess calibration information for standard camera or lens types and this data is used thus allowing to remove distortion. In case a camera was customized in some way all calibration information can be added by the user.

Two softwares that use different approaches to SfM were tested. Agisoft Photoscan (AS) is known to be based on traditional stereo-image analysis and performs best in objects exterior modelling. Software looks thru pictures in order to find matching pairs - left and right image and basing on them a 3D scene and 3D location of cameras is extracted. It is mostly advised to be used with drone-based pictures. Bentley ContextCapture (CC), was designed for out-door and in-door modeling and uses Perspective-n-Point (PnP) algorithm. PnP estimates the position of a camera given as a set of $n-3 D$ points and their corresponding $2 \mathrm{D}$ projections in the image (Wu, Y., 2006). In case of CC minimum $\mathrm{n}$ is 3 . Agisoft Photoscan (AS) and Bentley's ContextCapture (CC) programs were used in order to create 3D models of exterior of church and monastery, altar of the Assumption Church and remains of fortified castle tower. In case of Latyczów Church/Monastery complex facades and inner parts of the church are almost white with limited number of distinctive elements, painted in pail gold. Elements other than white are almost identical to each. This lack of contrast and unique features leads to various errors in the processing of Structure-from-motion. Castle walls on the other hand are light grey, have a lot of distinctive elements and can be used as reference models since the results, in general, should be similar in CC and AS. Survey was done in September of 2018 and lasted one day. Number of pictures: facade -986 , castle 320 , altar - 273. In order to scale obtained models five black and white $20 \mathrm{~cm}$ targets, paced in various locations were used. Models were calculated in medium quality in bought software's with the use of the same computer (8 GB RAM, Geforce 960 M graphic).

The comparison was divided into two groups visual and numerical. Visual analysis describes a number of details obtained in mesh model and point cloud, their accuracy in the sense of general shape, number of artifacts, number of wholes and quality of texture. Numerical analysis describes the divergence in distance between separate parts of the models that show if they represent the same shape.

\section{VISUAL ANALYSIS}

Visual analysis started with assessing the range of MESH and point cloud models of the object. In case of the altar and castle results were similar. In case of monastery results differ. AS produced a full model of the monastery (excluding the roof) with one noticeable error. One of the aisles was slightly misshapen and two similar roof towers shifted at about 0.5 meters appeared. This was due to lack of proper access at this side of the building during survey. In case of CC only the front of the building was modelled, other walls were misplaced and rotated. $\mathrm{CC}$ is more susceptible to pictures done at an angle and requires more pictures. Further analysis were performed on this part of the facade (table 1.). 


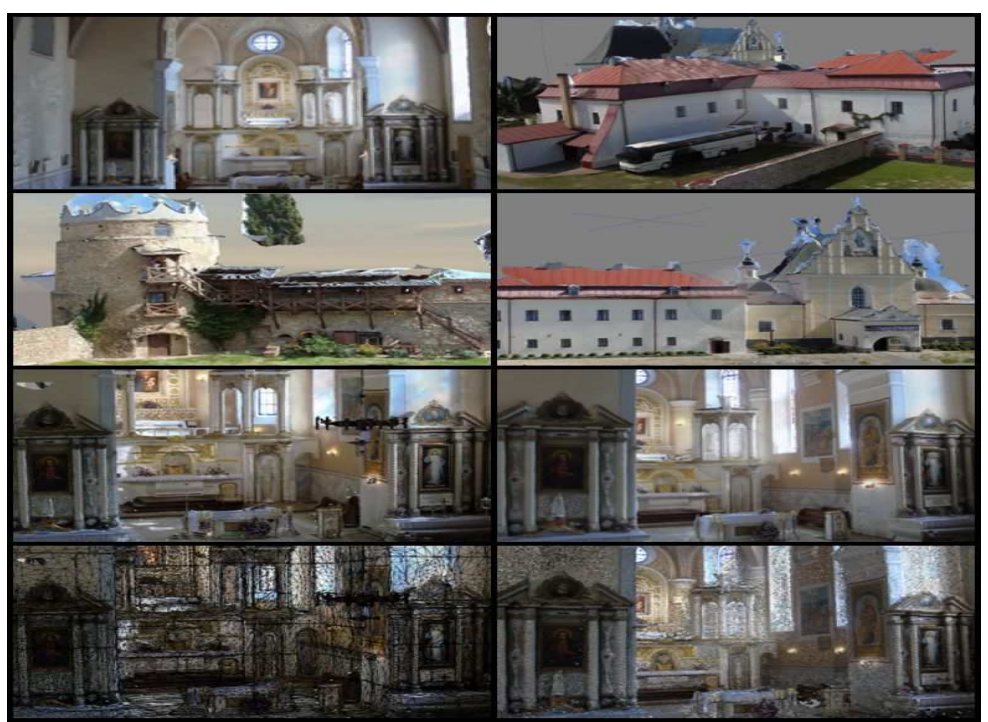

Figure 1. Mesh models from ContextCapture (Left) and Agisoft (Right)

Table 1. Visual comparison of models from Agisoft Photoscan and Bentley Context Capture

\begin{tabular}{|c|c|c|c|}
\hline Feature & Object & Agisoft & Context Capture \\
\hline \multirow[t]{3}{*}{ Artifacts } & Castle & $\begin{array}{l}\text { Large number of artifacts mostly in top } \\
\text { parts of the roof, associated with sky }\end{array}$ & $\begin{array}{l}\text { Smaller number of artifacts, two types } \\
\text { associated with the sky and mistakenly } \\
\text { calculated top parts of the roof. }\end{array}$ \\
\hline & Monastery & $\begin{array}{l}\text { Large number of artifacts mostly in top } \\
\text { parts of the roof, associated with sky }\end{array}$ & $\begin{array}{l}\text { Minimum number or artifacts mostly } \\
\text { around top parts of the roof }\end{array}$ \\
\hline & Altar & No & No \\
\hline \multirow[t]{3}{*}{ Voids } & Castle & No voids & No voids \\
\hline & Monastery & No voids & Voids appear in large flat white areas \\
\hline & Altar & No voids & Voids appear in large flat white areas \\
\hline \multirow{3}{*}{$\begin{array}{l}\text { Falsely } \\
\text { filled } \\
\text { voids }\end{array}$} & Castle & $\begin{array}{l}\text { Filled voids between balustrade elements, } \\
\text { windows do not represent proper depth }\end{array}$ & $\begin{array}{l}\text { Alost no filled voids in balustrade, } \\
\text { proper depth of windows }\end{array}$ \\
\hline & Monastery & $\begin{array}{l}\text { Portal arches do not have a proper shape, } \\
\text { partially filled, cross is falsely connected to } \\
\text { the floor and wall, lamps do not maintain } \\
\text { proper shape }\end{array}$ & No falls fillings \\
\hline & Altar & $\begin{array}{l}\text { Columns do not maintain proper shape, } \\
\text { falsely connected to the walls or arches. } \\
\text { Angel's wings connected to the altar portal. }\end{array}$ & $\begin{array}{l}\text { One of angel's wings connected to the } \\
\text { altar portal. }\end{array}$ \\
\hline \multirow{3}{*}{$\begin{array}{l}\text { Model } \\
\text { Range }\end{array}$} & Castle & similar & similar \\
\hline & Monastery & All buildings & Only front \\
\hline & Altar & similar & similar \\
\hline \multirow{3}{*}{$\begin{array}{l}\text { MESH } \\
\text { versus } \\
\text { point } \\
\text { cloud }\end{array}$} & Castle & $\begin{array}{l}\text { Point cloud is more detailed than mesh } \\
\text { (cross outside the walls exist on the point } \\
\text { cloud, does not on a MASH) }\end{array}$ & Same amount of detail \\
\hline & Monastery & $\begin{array}{l}\text { Point cloud is more detailed than mesh } \\
\text { (cross, parts of the roof) }\end{array}$ & Same amount of detail \\
\hline & Altar & $\begin{array}{l}\text { Point cloud is more detailed than mesh } \\
\text { (details of the candles, hanging lamp ) }\end{array}$ & Same amount of detail \\
\hline \multirow[t]{3}{*}{$\begin{array}{l}\text { Details } \\
\text { represent- } \\
\text { ation }\end{array}$} & Castle & $\begin{array}{l}\text { Good representation, lamps and protruding } \\
\text { elements modelled poorly, elements are } \\
\text { misshapen or flatten and ingrained in to the } \\
\text { walls }\end{array}$ & $\begin{array}{l}\text { More detailed model (bricks, plants, } \\
\text { leafs, balustrades) good representation } \\
\text { of protruding elements, correct shape } \\
\text { and placement }\end{array}$ \\
\hline & Monastery & Good representation & Good representation \\
\hline & Altar & $\begin{array}{l}\text { Mild representation (gold ornaments } \\
\text { visible only via texture, not visible on a } \\
\text { clean mesh model), poor representation of } \\
\text { lamps Figurers (Figurers with limited } \\
\text { number of features, lamps not modelled or } \\
\text { misshapen) }\end{array}$ & $\begin{array}{l}\text { Mild representation (gold ornaments } \\
\text { visible only via texture, not visible on a } \\
\text { clean mesh model), good representation } \\
\text { of lamps, and Figurers, visible 3D shape }\end{array}$ \\
\hline
\end{tabular}


ContextCapture models in all accounts provided the user with more detail. Pounding elements were modelled correctly, there were almost no false connections of those elements to surrounding walls. Also, there were no incorrect fillings of voids, stairs balustrade, porches and arches resumed their real shape. Small detailed objects looked more realistic. However, $\mathrm{CC}$ also produced more voids in white or almost white areas where AS managed to keep constant surface. CC and AS were similarly unable to give many details in gold ornaments or finishes of the altar. However CC model had more depth (AS model had almost flat areas where ornaments were supposed to be placed). The general review of the texture is in favour of CC. Textures have better colour and blend, give a more realistic effect. CC also gives more detailed point cloud and in total gives more small elements in MESH model.

\section{NUMERICAL ANALYSIS}

Numerical analyses for the castle, monastery and altar for both point clouds and mesh models were made in the CloudCompare v2.10 software. Due to very large cloud volumes of the castle and the monastery from $\mathrm{CC}$, the total number of points received was reduced thrice to improve time of calculation. The density of each of the clouds was determined using the Density function. The Precise method was applied, based on the calculation of the number of neighbours for each $\mathrm{N}$ point within a sphere with a given radius. The original number of points and the determined density (presented using histograms) are summarized in Table 2. The clouds originating from CC are characterized by a significantly higher number of points reaching several hundred million. It also translates into a much higher density even in the case of reducing the number of points taken into account in the calculations. It is worth to mention that during calculations the same number of photos was used and similar settings were used in CC and AS.
Distance differences between point clouds and mesh models (functions Cloud / Cloud dist. and Cloud / Mesh dist.) were also determined. Data from AS were set as Reference, whereas data from $\mathrm{CC}$ as Compared. The visible range of the result was limited in order to omit the excess of one data over the other in the analysis. Comparison of the point clouds shows that although the general shape of the point clouds is similar points diverge for at least $10 \mathrm{~cm}$ not only at the edges of the model (that was expected) but also at more difficult and more detailed elements. Comparison of mesh models shows similar results as point clouds.

Table 2. Numerical comparison of point clouds from Agisoft Photoscan and Bentley Context Capture

\begin{tabular}{|c|c|c|c|}
\hline Feature & Object & Agisoft & ContextCapture \\
\hline \multirow{3}{*}{$\begin{array}{l}\text { Number of points } \\
\text { in point cloud } \\
\text { (primary) }\end{array}$} & Castle & 3781436 & 234681819 \\
\hline & Monastery & 15820129 & 177349739 \\
\hline & Altar & 5718217 & 32371284 \\
\hline \multirow{4}{*}{$\begin{array}{l}\begin{array}{l}\text { Point cloud } \\
\text { density } \\
0.05 \mathrm{~m} \text { ) } \\
\text { (radius }\end{array} \\
\text { In the case of CC } \\
\text { the number of } \\
\text { points for castle } \\
\text { and monastery } \\
\text { has been reduced } \\
\text { thrice. }\end{array}$} & Castle & Volume density $(r=0.05)$ (3781436 values) [256 classes] & \\
\hline & & 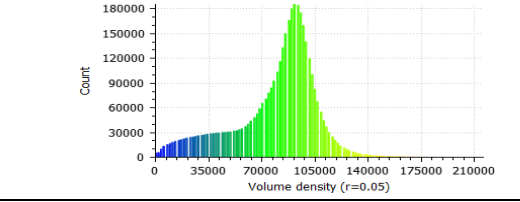 & Volume density (r=0.05) (780000000 values) [256 classes] \\
\hline & Monastery & 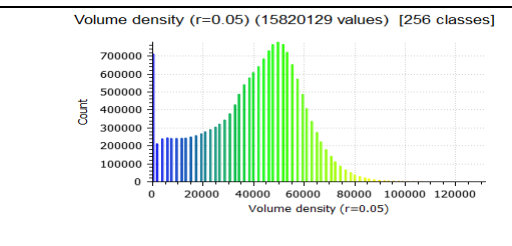 & 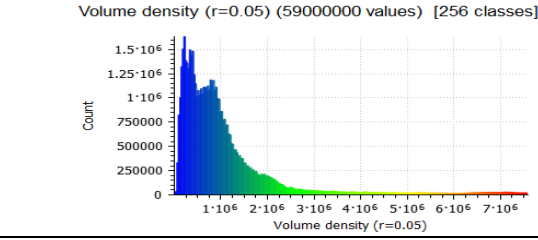 \\
\hline & Altar & 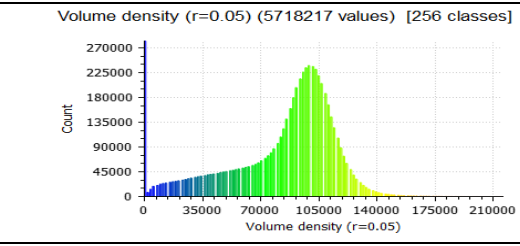 & 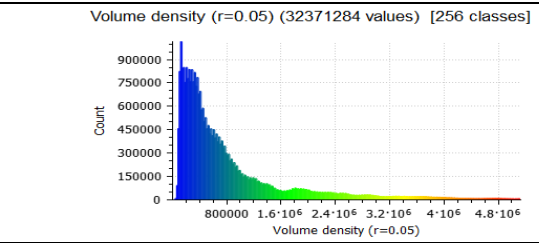 \\
\hline
\end{tabular}




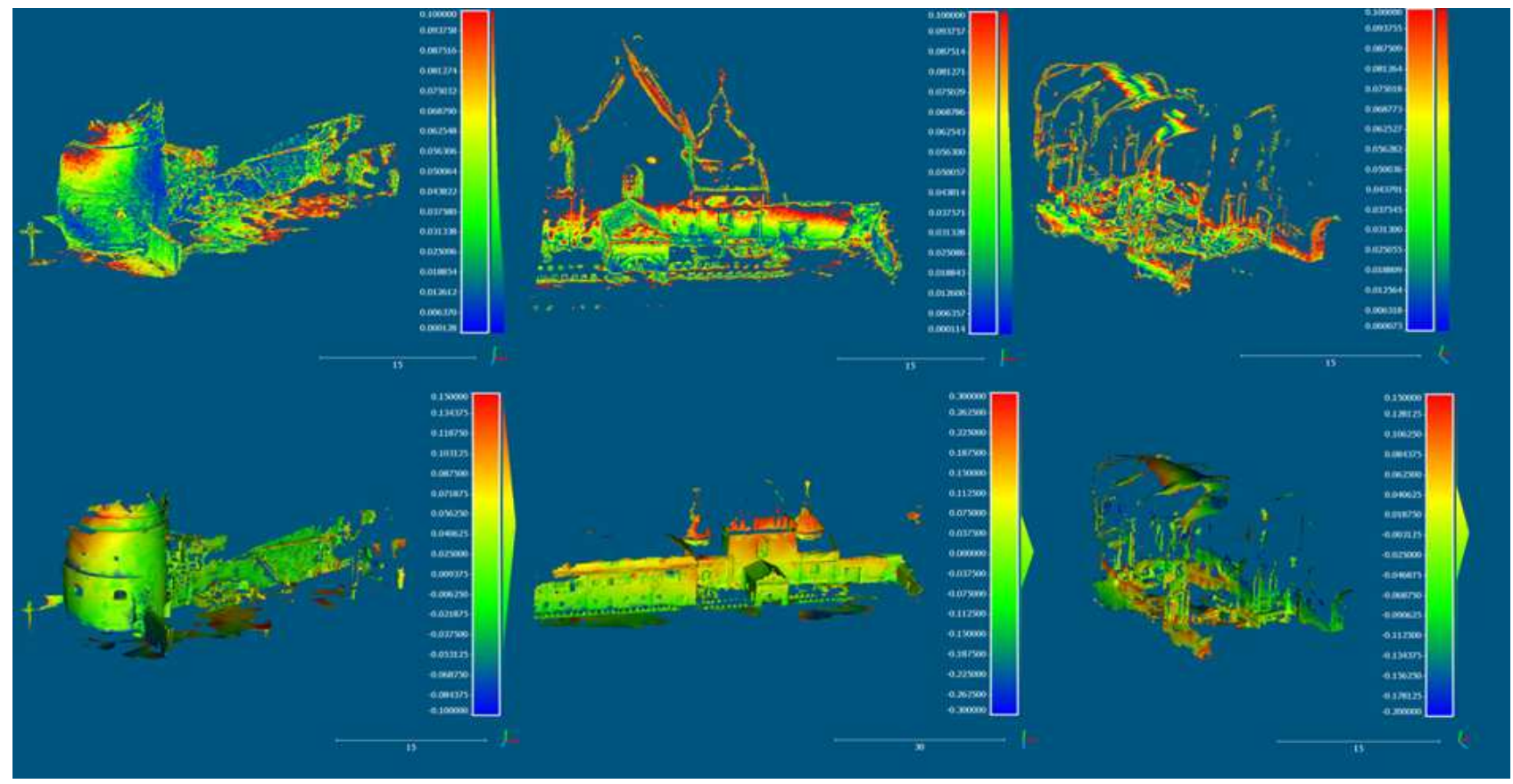

Figure 2. Up: Cloud to cloud distance; Down: mesh to mesh distance (castle; monastery, altar)

\section{DISCUSSION AND CONCLUSION}

The aim of this study was to show if SfM algorithms allow for creation of 3D models of white or shiny facades and walls Gao $Y, 2014)$. General results show usage of different software's results with differ in accuracy, range and quality. Agisoft provides usually larger range of modelled object (monastery) and less gaps in models. ContextCapture produces many more false voids in the white areas. It was observed on the facade and on the back of the altar. On the other hand AS creates less detailed object, this leads to false void filling (arches, stairs, windows). The shape of smaller elements in CC is more accurate and the model provides more details, does not create false fillings in voids. Mesh models from CC look more like handmade wireframe models that a mesh providing a large number of straight lines, flat surfaces etc., whereas AS looks like a classical mesh with shifted, wavy lines on the edges. In case of mesh model, AS produces more artefacts that need to be removed. Point clouds in CC and AS look similar but mesh models differ. In case of standalone objects (cross) AS does not deliver mesh. General overview shows that however it is possible to create a model of all objects white elements provide with many errors. In case of CC most significant was randomly occurring gaps in white areas. In case of AS number of gaps was limited but in case of the altar is was apparent that whiteon-white elements do nor model property (white angels on top of a white wall, white columns on white walls etc.). This problem was almost not existed CC.

Numerical analysis shows distance differences between models. With the pixel size of a few $\mathrm{cm}$ differences of $15 \mathrm{~cm}$ and up can be viewed as significant. As it is visible in the Figureures smallest count and dispersion of deference's appears in the castle. This is due to large amount of details on the object. In case of the facade errors grow going up the wall (with growing pixel size). It could also result from placement of control points on the lower part of the facade. Errors on this object are biggest but this is due to its size. Dispersion of the distance differences is most significant in the case of the altar. Since white areas are mixed with fresco it can be observed that parts with more colour fit each other better than white and shiny-gold elements. This object being $1 / 3$ the height and $1 / 5$ the width of other two shown most errors.

This study shows that while creating a 3D model with structurefrom-motion algorithms it is important to plan what software is going to be used. For more detailed work $\mathrm{CC}$ is more useful but for modelling larger areas with less detail AS can be used. White objects are significantly harder to model and results are not always predictable. They provide models with voids or misshapen elements. Case of the altar shows that while using the same data and similar settings results can differ in shape, size and level of detail (LOD). While this study shows slight advantage in ContextCapture (basing on LOD, accuracy, amount of data) AS has an upper hand of creating almost void less 3D mesh.

Creation of a 3D model of archaeological or heritage sides is important since it aids in preservation of their shape and structure. It is especially important with objects of extensive tourist visits. 3D models aloe to better plan tourist movements and allow for creation of extra escape roots (Krawczyk, A., 2016.

\section{ACKNOWLEDGEMENTS}

The research and application presented in this article was carried out as part of statutory founding of Faculty of Mining 
Surveying and Environmental Engineering (no 11.11.150.005). We would like to thank Priest Adam Przywuski a Rector of Assumption Church in Latyczów for all provided help and allowing access to the Castle-Church-Monastery complex.

\section{References}

Chiabrando, F. Donadio, E. Rinaudo, F. (2015). SfM for ortophoto generation: a winning approach for cultural heritage knowledge. The International Archives of the Photogrammetry, Remote Sensing and Spatial Information Sciences, Volume XL5/W7, 91-98, doi: 10.5194/isprsarchives-XL-5-W7-91-2015.

De Reu, J. Plets, G. Verhoeven, G. De Smedt, P. Bats, M. Cherrette, B. De Maeyer, W. Deconynck, J. Herremans, D. Laloo, P. Van Meirvenne, M. De Clercq, W. (2013). Towards a three-dimensional cost-effective registration of the archeological heritage. Journal of Archeological Science, 40, 1108-1121, doi: 10.1016/j.jas.2012.08.040.

Doneus, M. Verhoeven, G. Fera, M. Briese, Ch., Kucera, M. Neubauer, W. (2011). From Deposit to Point Cloud - a Study of Low-Cost Computer Vision Approaches for the Straightforward Documentation of Archaeological Excavations. Geoinformatics. 6 (XXIIIrd International CIPA Symposium). 81-88, doi: 10.14311/gi.6.11.

Gao Y., Luo J., Qiu H. and Wu B. (2014), Survey of structure from motion. Proceedings of 2014 International Conference on Cloud Computing and Internet of Things, Changchun, 72-76, doi: 10.1109/CCIOT.2014.7062508.

Green, S. Bevan, A. Shapland, M. (2014). A Comparative Assessment of Structure from Motion Methods for Archaeological Research. Journal of Archaeological Science, Volume 46, 173-181, doi: 10.1016/j.jas.2014.02.030.

Joachimski, J. Mierzwa, M. and Tokarczyk, R. (2007). 3D visualization in the promotion of cultural heritage. Annals of Geomatics, T.5, z.8, 162-172.

Krawczyk, A., Stawarczyk, Z. Wojciechowski, D. (2016). Koncepcja trójwymiarowego modelu wyrobisk Kopalni Soli Wieliczka dla poprawy warunków zarządzania bezpieczeństwem ruchu kopalni (The concept of a threedimensional model of excavations of the Wieliczka Salt Mine to improve the conditions of management of mine traffic safety) Przegląd Górniczy T. 72, nr 1, p.11-17.

Ryan, J.C. Hubbard. A.L. Box, J.E. Todd, J. Christoffersen, P. Carr, J. R. Holt, T.O. and Snooke N. (2015). UAV photogrammetry and structure from motion to assess calving dynamics at Store Glacier, a large outlet draining the Greenland ice sheet, The Cryosphere, 9, 1-11, doi:10.5194/tc-9-1-2015.

Shah, Y. Raut, S. Wadle, S. Patil, S. (2018). A study of structure from motion photogrammetry for generating 3D model from 2D images. IOSR Jornal of Engineering (IOSRJEN), ISSN (e): 2250-3021, ISSN (p): 2278-8719, Volume 4, 72-76.

Sona, G. Pinto, L. Pagliari, D. Passoni, D. and Gini, R. (2014). Experimental analysis of different software packages for orientation and digital surface modeling from UMV images, Earth Science Information, 7(2), 97-107, doi: 10.1007/s12145013-0142-2.

Strach M., A. Tama P. Lewinska, 2016, Comparative Analysis of 3D Models Made with Various Technologies on the Example of Altar in the Wang Temple in Karpacz, from: https://www.researchgate.net/publication/320653918_Comparat ive_Analysis_of_3D_Models_Made_with_Various_Technologi es_on_the_Example_of_Altar_in_the_Wang_Temple_in_Karpa cz (accessed Nov 12 2018).

Szumił, H.I. (2015). "Nigdym ja ciebie ludu, nie rzuciła" Z dziejów latyczowskiej Ikony, Wydawnictwo Diecezjalne i Drukarnia w Sandomierzu (in polish).

Westoby, M.J. Brasington, J. Glasser, N.F. Hambrey, M.J. and Reynolds J.M. (2012). Structure-from-Motion' photogrammetry: a low-cost, effective tool for geoscience applications. Geomorphology, 179, 300-314, doi: 10.1016/j.geomorph.2012.08.021.

Wu, Y. Hu, Z. (2006), PnP Problem Revisited, Journal of Mathematical Imaging and Vision 24, 131-141, doi: 10.1007/s10851-005-3617-z.

Verhoeven, G. Taelman, D. Vermeulen, F. (2012). Computer vision based orthophoto mapping of complex archaeological sites: the ancient quarry of Pitaranha. Archaeometry, 54.6, 1114-1129, doi: 10.1111/j.1475-4754.2012.00667.x.

\section{References from websites:}

http://www.cloudcompare.org/doc/qCC/CloudCompare\%20v2. 6.1\%20-\%20User\%20manual.pdf (CloudCompare web page, last access: 05.11.18).

http://www.agisoft.com/support/tutorials/beginner-level/ (Agisoft Photoscan webpage, last access: 05.11.18).

https://www.acute3d.com/tutorials/ (ContextCapture webpage, last access: 05.11.18). 